\title{
Energy Saving as a Component of the Strategic Development of the Tire Enterprises
}

\author{
Tkachenko A.M, Chernysheva O.M, Sevast yanov R.V, Krainik O.M
}

\begin{abstract}
The article is devoted to the formation of the scientific and methodic providing based on the estimation of the product competitiveness for the energy saving as for a component of the tire enterprises strategic development. Since a car consumes $10 \%$ of fuel due to tires, it is advisable to take the energy efficiency into account as an impact factor on the production and consumer characteristics of tires when estimating of the competitiveness of the tire enterprises products. The quantitative estimation of the level of competitiveness of the tire products by the integral indicator that is calculated as an average arithmetic indicator weighted according to the conditions of sales on the markets of each group of tires on the base of the complex indicators of competitiveness for every model of standard size of tires in the conditions of production and consumption has been offered in this research work. This approach to the estimation of the product competitiveness allows tire enterprises to take into account aspects of the energy efficiency in the production and consumption of the model of standard size of tires as well as to make the market positioning of the energy-saving tires. It has been offered to consider the energy saving in the tire enterprises at the production and consumption aspects, which should be taken into account in the system of the enterprises' strategic development as a necessary condition of the product competitiveness providing. Based on the components of the integral indicator of estimation of the level of competitiveness of the model of standard size of tires, it was proved that the rolling resistance coefficient and the content of silica acid filler are the defining indicators of energy efficiency in the group of tires for passenger cars. The product energy efficiency should be estimated by means of the indicators of tire weight and pressure level inside the tire in the groups of tires for trucks and tires for agricultural machines.
\end{abstract}

Key words: competitiveness of the products, energy saving, strategic development of the enterprise, tire production

\section{INTRODUCTION}

The current stage of development of the tire production is characterized by trends of growth of the level of the population motorization, the changing customer aggravation of environmental problems of production and

Revised Version Manuscript Received on October 15, 2019.

Tkachenko A.M, Doctor of Economic Science, Professor, Head of the Department of Entrepreneurship, Trade and Stock Exchange, National University "Zaporizhia Politechnic", Zaporizhia, Ukraine, Europe. (Email: alla0676128584@gmail.com)

Chernysheva O.M, PhD in Economics, Associated Professor of Management and Finance Department, State Higher Education Institution "Ukrainian State University of Chemical Technology", Dnipro, Ukraine, Europe. (Email: chernysheva197411@gmail.com)

Sevast yanov R.V, $\mathrm{PhD}$ in Economics, Associated Professor of the Department of Entrepreneurship, Trade and Stock Exchange, National University "Zaporizhia Politechnic", Zaporizhia, Ukraine, Europe. (Email: rvs_zp@ukr.net)

Krainik O.M, $\mathrm{PhD}$ in Economics, Associated Professor of the Department of Entrepreneurship, Trade and Stock Exchange, National University "Zaporizhia Politechnic", Zaporizhia, Ukraine, Europe. (Email: elenakrainik2@gmail.com) requirements to the operational characteristics, the

operation of tires as well as the formation of a regulatory framework for their solution in the countries with high volume consumption of tires. In these conditions the strategic management system of the world leading manufacturers includes a high-level formed their own scientific base that allows carrying out the researches on the apply of environmentally friendly materials in the production and providing the operational characteristics of tires at a new level of quality to increase the products' competitiveness in the globalization of the automotive market.

\section{ANALYSIS OF PUBLICATIONS AND FORMULATION OF THE PROBLEM}

The problems of the development of the Ukrainian chemical industry in general, and of the tire production in particular, have been investigated by D. E. Gladkykh, T. V. Kovenia, O. V. Liakhovska, I. I. Pavlenko, P. G. Pererva, G. Z. Shevtsova. Especially, T. V. Kovenia notices among the negative trends of the Ukrainian chemical industry development the decline in energy efficiency in the most chemical productions [4]. O. V. Liakhovska points out that high cost of gas is one of the causes of the unprofitableness of Ukrainian enterprises of the chemical industry [5]. In opinion of P. G. Pererva, the raw materials, energy, and ecological factors should be taken into account in the formation of the chemical enterprises strategy [10]. I. I. Pavlenko indicates the resource intensity of the production as a component of the estimation of the potential to increase the competitiveness of the chemical industry enterprises [10]. G. Z. Shevtsova pays attention to energy efficiency as one of the reason to create the knowledge-intensive small-tonnage productions in the segments of special and fine chemistry [14]. The necessity of carrying out of the neoindustrial strategy of development of the Ukrainian chemical industry based on the energy efficiency, innovations and competitiveness has been proved by D. E. Gladkykh [1]. This strategy is directed on the quality reformatting and modernization of the outdated production capacity of the chemical complex.

Therefore, the necessity to ensure energy efficiency of the chemical industry enterprises proves the expediency of energy saving as a component of the tire enterprises strategic development based on the production of competitive products. 


\section{THE PURPOSE OF THE ARTICLE}

The purpose of the article is to form a scientific and methodical providing based on the estimation of the product competitiveness for the energy saving as for a component of the tire enterprises strategic development.

\section{RESULTS}

The global trends in the tire markets are the increase in requirements to the environmental friendliness and economy of tires. Furthermore, these requirements form the parameters of the estimation of quality of tires by the consumers and determine the directions of competitiveness development of the tire enterprises.

Tire is a complex product that consists of a large number of design and technological compromises as well as has the ability to provide movement and helm of motorized vehicles in a wide range of operating modes. Pneumatic tires for tractors and cars are intended for providing the necessary towing and handling characteristics as well as for absorbing small shocks and soften bumps while hitting obstacles.

In the process of car driving, about $10 \%$ of fuel is consumed due to tires. For this reason, the energy efficiency should be taken into account in estimation of the competitiveness of the tire enterprises products as an impact factor on the production and consumer characteristics of tires.

The modern trends in the tire production are: reduction of resource intensity of production, above all, material and energy intensity; changing of recipes of rubber compounds, including the application of new and recycled materials; changing of design parameters of tires; the introduction of long-term programs to improve the environmental friendliness of production; modernization of production in the areas of increase in productivity as well as quality, and expanding the range of products; building of new plants in the countries with a high demand for tires; integration of tire manufacturers with raw material manufacturers; establishment of producers associations. In the same time, the trends of growth of the global car market, enlargement of the average standard size of tires in the original picking, growth in the demand for long-life tires and retreaded tires, increase in the requirements for safety of tires for passenger cars, high elasticity of demand depending on the price of fuel as well as rise in demand for the energy-saving tires are observed in the consumption of tires.

The energy costs amount from 5\% to $9 \%$ in the cost structure for the production of tires. Above all, the production of tires for trucks is the most energy intensive (Table I). The main items of energy costs in the cost of production are costs of electricity and water vapour.

Table I. The cost structure for the production of tires, $\%$

\begin{tabular}{|l|l|l|l|l|}
\hline Group of tires & $\begin{array}{l}\text { Materi } \\
\text { al cost }\end{array}$ & $\begin{array}{l}\text { Ener } \\
\text { gy } \\
\text { cost }\end{array}$ & $\begin{array}{l}\text { Labou } \\
\text { r costs }\end{array}$ & $\begin{array}{l}\text { Othe } \\
\text { r costs }\end{array}$ \\
\hline $\begin{array}{l}\text { Tires for } \\
\text { agricultural } \\
\text { machines }\end{array}$ & 72 & 7 & 2 & 19 \\
\hline Tires for trucks & 73 & 9 & 2 & 16 \\
\hline $\begin{array}{l}\text { Tires for passenger } \\
\text { cars }\end{array}$ & 60 & 5 & 4 & 31 \\
\hline
\end{tabular}

High energy intensity is a part of the environmental problems of the tire production. In addition, they include application of environmentally harmful materials (synthetic rubber, carbon black), air pollution indoor of production (volatile organic substances, polycyclic aromatic hydrocarbons, N-nitrosamines, industrial dust), contamination of water drains. Fuel consumption as well as high noise during the movement of the car, formation a rubber dust (in Germany - 65 thousand tons per year, in the USA - 90 thousand tons), and growth of the amount of used tires are regarded as environmental issues in the consumption of tires.

The problem of the utilization of used tires has most acutely arisen in the European Union. According to [2], the number of used tires in the European countries amount more than 3.2 million tons, in the biggest countries (Germany, Great Britain, France, Italy, Spain, and Poland) it is in the range from 250 thousand tons to 600 thousand tons per year. In Russia every year 1 million tons of used tires is formed, whereas in Ukraine 180 thousand tons of tires exhaust their lifespan, and the statistics of the used tires is absent, but there is enough stocks to start the process of establishing the recycling plants [2], [11].

Recycling (for the purpose of obtaining materials and energy), reuse and restoration of a tread amount $96 \%$ of total recycling of used tires. In $2009-201218$ countries of European Union utilized $90 \%$ of the annual stocks of used tires, Czech Republic - more than $70 \%$, moreover, the North European countries, where the manufacturer's responsibility system for utilization has been introduced more than 10 years ago, have $100 \%$ recycling volumes [2]. In Germany the increase in demand for the retreaded tires for trucks is observed, whereas in 2012 their part in the total sales of tires was $30 \%$ [12]. In Ukraine Open Joint Stick Company "Dniproshina" had a sector of the regenerate production. The large-scale utilization of used tires from all territory of the country was one of the perspectives of activity of this sector.

We offer to make a quantitative estimation of the level of competitiveness of the tire products by the integral indicator that is calculated as an average arithmetic indicator weighted according to the conditions of sales on the markets of each group of tires on the base of the complex indicators of competitiveness for every model of standard size of tires in the conditions of production and consumption using below mathematical representation,

$$
K_{i n t}^{m}=\mu^{g r} \times K_{p r}^{m}+\eta^{g r} \times K_{\text {cons }}^{m}
$$

where

$$
\begin{gathered}
K_{i n t}^{m} \\
K_{p r \text { and }}^{m} K_{\text {cons }}^{m} \quad \begin{array}{l}
\text { is the level of competitiveness of the model } \\
\text { of standard size of tires } \\
\text { and the complex indicators of the } \\
\text { competitiveness of every model of standard } \\
\text { size of tires for the conditions of production } \\
\text { and consumption in accordance } \\
\text { are the weighing indicators of the impact, in }
\end{array} \\
\begin{array}{l}
\text { accordance, of manufacturer capabilities and } \\
\text { customer requirements on the qualitative } \\
\text { and cost characteristics of the product taking } \\
\text { into account the conditions of sales on the } \\
\text { markets of each group of tires }
\end{array}
\end{gathered}
$$


This approach to the estimation of the product competitiveness allows tire enterprises to take into account aspects of the energy efficiency in the production and consumption of the model of standard size of tires as well as to make the market positioning of the energy-saving tires.

The increase in the energy efficiency is a component of the tires competitiveness according to the environmental friendliness and economy parameters. In the conditions of production the energy saving is determined by the equipment energy intensity (rubber mixing and vulcanizing), whereas in the consumption conditions it is determined by fuel consumption by car. Therefore, it is necessary to consider the energy saving in the tire enterprises at the production and consumption aspects, which should be taken into account in the system of the enterprises' strategic development as a necessary condition of the product competitiveness providing.

We also offer to estimate the complex indicator of quality for the model of standard size of tires in the conditions of consumption ( $K_{q_{-}}^{m}$ cons ) by the weighted average arithmetic indicator for the comparative individual indicators of tires' quality using below mathematical expression,

$$
K_{q_{-} \text {cons }}^{m}=\sum_{j} \gamma_{j} \frac{k_{c o n s_{-} j}^{m_{-} f}}{k_{c o n s_{-} j}^{s s_{-} b}}
$$

Where

\begin{tabular}{|c|c|}
\hline$k_{\text {cons }}^{m}{ }_{-j}^{f}$ & $\begin{array}{l}\text { is the actual value of the absolute } \\
\text { individual indicators of quality of the } \\
\text { model of standard size of tires obtained as a } \\
\text { result of tests }\end{array}$ \\
\hline$k_{c o n s_{-} j}^{s s_{-} b}$ & $\begin{array}{l}\text { is the value of the absolute individual } \\
\text { indicators of quality of the model of } \\
\text { standard size of tires for the base of } \\
\text { comparison }\end{array}$ \\
\hline$\gamma_{j}$ & $\begin{array}{l}\text { is the weighing indicator for the individual } \\
\text { indicators of quality of the model of } \\
\text { standard size of tires in the conditions of } \\
\text { consumption }\end{array}$ \\
\hline$j$ & $\begin{array}{l}\text { is the number of individual indicators of } \\
\text { quality of the model of standard size of } \\
\text { tires in the conditions of consumption }\end{array}$ \\
\hline
\end{tabular}

The complex indicators of the quality of separate standard size of tires should be formed on the base of individual indicators that are calculated by the parameters of economy, safety, comfortableness, environmental friendliness (for all groups of tires), and function (for the tires for trucks).

Two indicators, which determine the energy efficiency of every standard size of tires, have been allocated among the significant indicators of quality in each group of tires in the conditions of consumption. In particular, the rolling resistance coefficient and the content of silica acid filler are the defining indicators of energy efficiency in the group of tires for passenger cars (Fig. 1). It should be noted that the rolling resistance coefficient is the key impact indicator for the fuel consumption by car and the intensity of the formation of rubber dust during the movement of the car. The product energy efficiency in the groups of tires for trucks and tires for agricultural machines should be estimated by means of the indicators of tire weight and pressure level inside the tire.

The level of weight of indicators of energy efficiency as components of the indicator of tires' quality in the conditions of consumption is: for tires for passenger cars $10 \%$, for tires for trucks $12 \%$, for tires for agricultural machines $25 \%$ (Table II).

The efforts of leading world manufacturers are aimed at improving the level of quality of tire products according to key consumer characteristics: grip, rolling friction, aquaplaning, level of noise and vibration, protecting the tire against puncture, mileage, load and safety, the dependence of the pressure inside the tire on the mass of the load. 


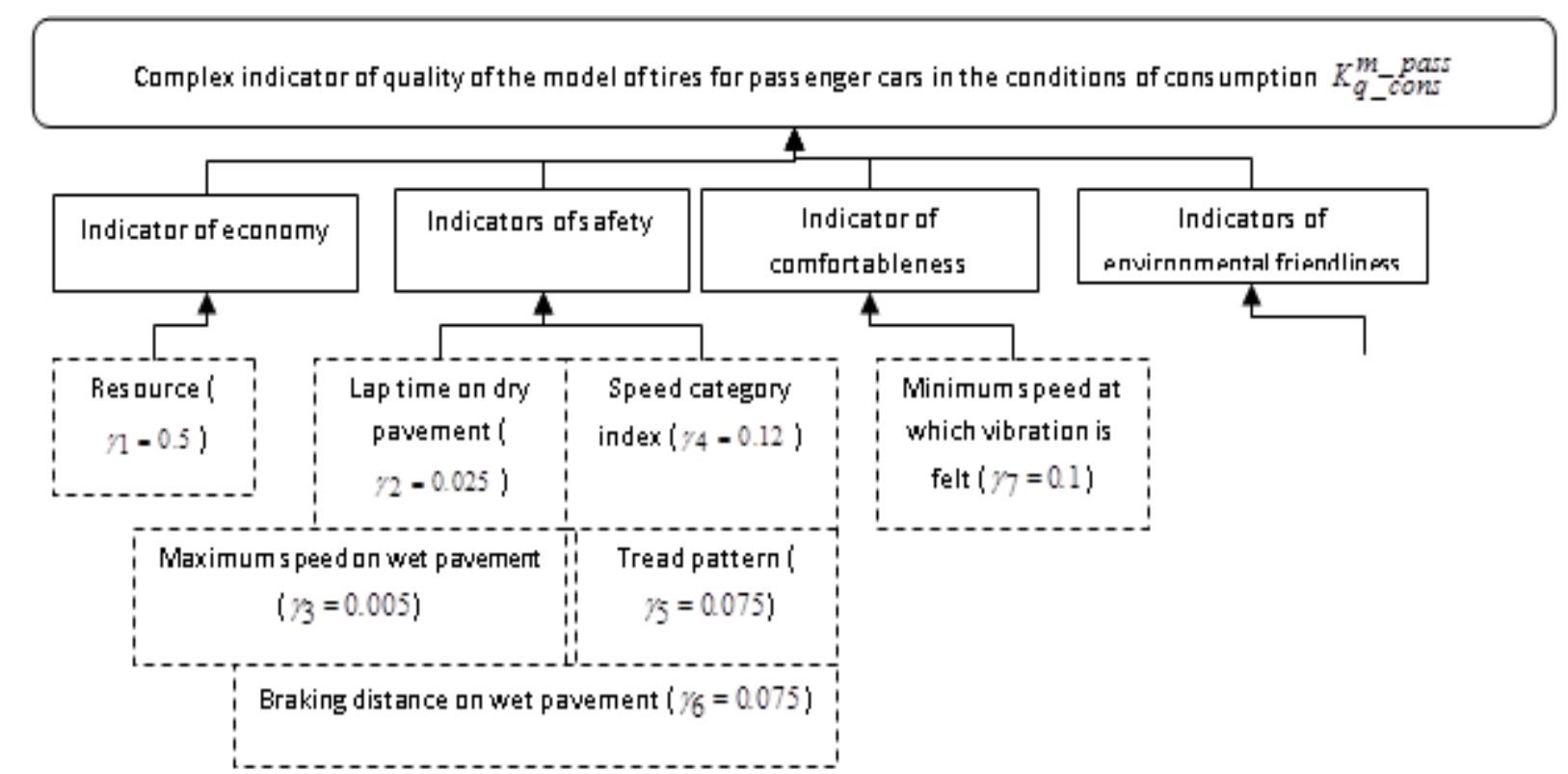

Fig. 1. Indicators of energy efficiency as components of the indicator of quality of the model of tires for passenger cars in the conditions of consumption

Innovative technologies provide quality, above all, due to material and construction components of tire production: the composition of the rubber compound and materials inside the tire, construction materials, elements, pattern and height of tread, construction of tire profile (Fig. 2). The leading world manufacturers create brand technologies that allow positioning of the energy-saving tires among products of the similar standard size in dependence on the competitive advantages in their production and consumption. The experience of developed countries proves that, if an innovative strategy is introduces, the industrial enterprises multiply output, sales, profitability, and efficiency of labour as well as accelerate capital turnover, and, finally, get the opportunity to supply new types of products to the market [7].

Successful experience in introducing energy saving programs is present in the Ukrainian tire production. In particular, in Open Joint Stock Company "Dniproshina" the autonomous source of electricity produced from water vapour (after the manufacture of tires) has been built. It provided $80 \%$ of production by own electricity

Table II. The indicators of energy efficiency as components of the estimation of competitiveness of the separate standard size of tires

\begin{tabular}{|c|c|l|}
\hline Title of the indicator & $\begin{array}{c}\text { The number of indicators of } \\
\text { estimation } \\
\text { competitiveness by the consumer } \\
\text { characteristics }\end{array}$ & $\begin{array}{l}\text { The weighting factor in the composition of } \\
\text { indicators for estimation the product } \\
\text { competitiveness for consumption conditions }\end{array}$ \\
\cline { 1 - 2 } Tires for passenger cars: standard size 175/70R13 & 0.075 \\
\hline $\begin{array}{c}\text { Rolling resistance } \\
\text { coefficient }\end{array}$ & 9 & 0.025 \\
\hline $\begin{array}{c}\text { The content of silica } \\
\text { acid filler }\end{array}$ & 9 & 0.07 \\
\hline Tires for trucks: standard size 9,00R20 & 0.05 \\
\hline $\begin{array}{c}\text { Tire weight } \\
\text { Pressure level inside the } \\
\text { tire }\end{array}$ & 9 & 0.15 \\
\hline Tires for agricultural machines: standard size 15,5R38 & 0.1 \\
\hline $\begin{array}{l}\text { Tire weight } \\
\text { Pressure level } \\
\text { inside the tire }\end{array}$ & 6 & \\
\hline
\end{tabular}




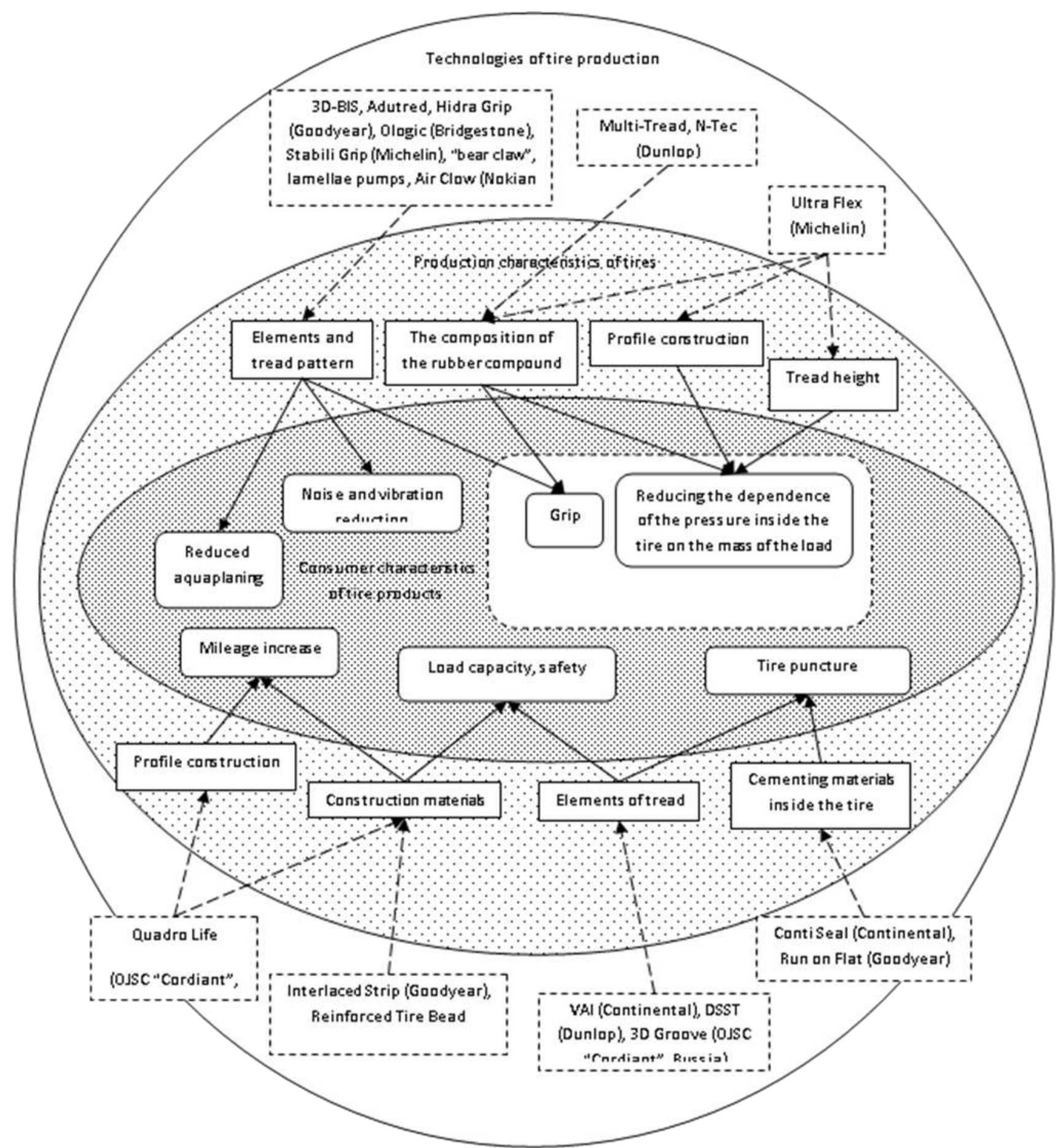

Fig. 2. Energy efficiency as a part of consumer characteristics of tire products

The leading world manufacturers - Bridgestone Corporation (Japan), Compagnie Generale des Etablissements Michelin (France), Goodyear Tire \& Rubber Company (USA), Continental A.G. (Germany), Sumitomo Rubber Industries, Ltd. (Japan), Yokohama Rubber Co., Ltd. (Japan), Cooper Tire \& Rubber Company (USA), Nokian Tyres (Finland) - conduct research and development on the application of new materials (including the materials from renewable sources) in the recipes of rubber compounds and constructions of tires to increase the energy efficiency of the products. Therefore, these materials are: bio-oils from canola, corn, rape and soy; fillers from rubbers made from dandelion and guaula; nanofibers from biological and synthetic materials; functionalized polymers (synthetic and natural rubber); microbiologically derived biopolymers; silica with a large surface (more than 200 square meters per gram); highly elastic steel cord to reduce tire weight; low weight materials for replacement of steel [9], [13], [15].

The producer of innovative chemical materials Dow Chemical Company (USA) and the producer of fine rubber powders Lehigh Technologies (USA) are planning to apply their technologies to modify the rubber particles. For instance, the world tire companies have produced 100 million new tires with fine rubber powders of Lehigh Technologies (USA) yet [3]. German company Me Wa Recycling Mashinen und Anlagenbau GmbH offers turnkey projects for

Published By:

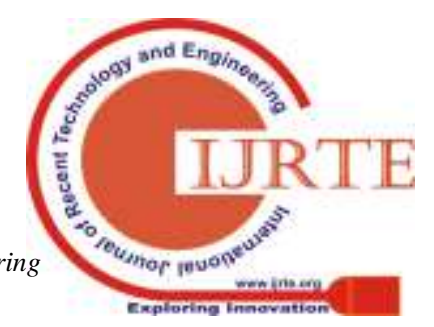


the organization of tire recycling. Fine activated rubber powder that added to the rubber compound within $20-60 \%$ is a result of this production [6].

Therefore, application of new materials in the tire production allows achieving the required properties of rubber with less energy costs for rubber mixing and vulcanization as well as reduces the rolling resistance while increasing tire grip for operation of tires. Achieving energy efficiency as a component of product competitiveness should become the basis for the strategic development of tire enterprises.

\section{CONCLUSIONS}

The scientific and methodical providing of the energy saving in the tire production has been formed on the base of estimation of the product competitiveness according to the parameters of environmental friendliness and economy. In the system of strategic management of the tire enterprises the energy saving should be considered in the production and consumption aspects. The innovative technologies of the world leading manufacturers cover the creation of competitive advantages in the energy saving through application of new materials, changing the construction parameters of tires as well as improvement of consumer characteristics of products. These competitive advantages will become the base of the positioning of the energy-saving tires among products of the similar standard size.

\section{REFERENCES}

1. Gladkykh, D., "The Transformation of the Global Market of Chemical Products in the Global Crisis." Extended abstract of $\mathrm{PhD}$ thesis, Donetsk National University, 2016.

2. Hrankin, O. and Zhytnytskyi, A., "Activization of the Utilization Productions of the Automotive Rubber Tires in Ukraine," Economic Nobel Bulletin, 1 (2014): pp. $128-132$.

3. "Greener materials will be developed for tire workers," Chemistry of Ukraine, 21 (2011): P. 22.

4. Kovenia, T., "The Systematic Analytical Assessment of Major Changes in the Ukrainian Chemical Industry in 2017 and Previous Years," Chemical Industry of Ukraine, 3 (2017): pp. 19-46.

5. Liakhovska, O., "The Analysis of the Modern State of the Ukrainian Chemical Industry Development," Market Infrastructure, 23 (2018): pp. 50-54.

6. Morozov, Yu., Reznichenko, S. and Konikova, T., "Conference "Rubbers, RTG, Tires: Traditions and Innovations," Kauchuk I Rezina, 2 (2011): pp. 40-43.

7. "World Market: Advanced Technologies for the Tire Industry," Chemistry of Ukraine and World, June 12, 2013,

http://ukrchem.dp.ua/2013/06/12/mirovoj-rynok-perspekt ivnye-texnologii-dlya-shinnoj-promyshlennosti.html.

8. Pavlenko, I., "Evaluation of Potential to Increase the Enterprise Competitiveness of Chemical Industry," Theoretical and Practical Aspects of Economic and Intellectual Property, 2 (12), 3 (2015): pp. 8-13.

9. "Tire Recycling - is an Advanced Business," Chemistry of Ukraine, 10 (2013): pp. 27-28.

10. Pererva, P., "Formation of the Strategy of Development of the Chemical Industry Enterprises," Bulletin of the National Technical University "KhPI", 21 (2013): pp. 112-119.

11. Pozhuieva, T., "Enterprise Innovative Strategy in the Modern Conditions," Bulletin of Economic Science of
Ukraine, 1 (2010): pp. 163-167.

12. Riazanov, V., "Finnish Ski Track," Kauchuk I Rezina, 1 (2012): pp. 39-43.

13. "USA: Goodyear uses rice husk ash for tire production," Chemistry of Ukraine and World, September 30, 2014, http://ukrchem.dp.ua/2014/09/30/ssha-goodyear-ispolzue t-pepel-iz-risovoj-sheluxi-dlya-proizvodstva-shin.html\#m ore-44255.

14. Shevtsova, G. "Transformation of Conceptual Approaches to Managing the Development of Chemical Industry within the Neo-Industrialization Context," Economics and Law. Series: Economics, 2 (2016): pp. 146-156.

15. "Japan: company Bridgestone Has Launched Passenger Tires from Rubber Made from Guaula Juice," Chemistry of Ukraine and World, October 13, 2015, http://ukrchem.dp.ua/2015/10/13/yaponiya-kompaniya-br idgestone-vypustila-legkovye-shiny-iz-kauchuka-poluche nnogo-iz-soka-gvayuly.html\#more-62288.

\section{AUTHORS PROFILE}

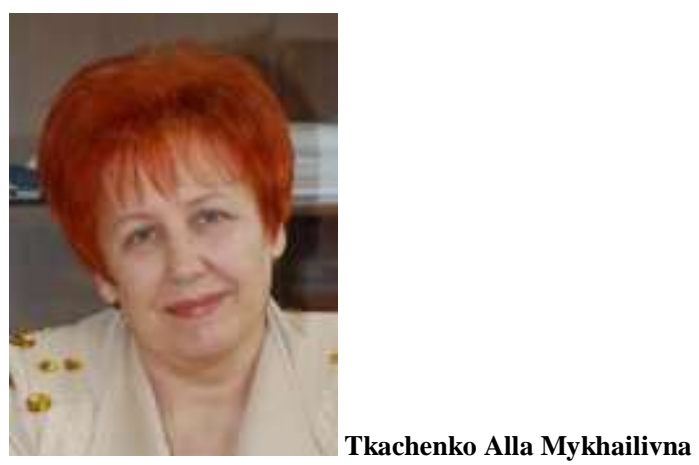

Doctor of Economic Science, Professor, Head of the Department of Entrepreneurship, Trade and Stock Exchange, National University "Zaporizhia Politechnic", Zaporizhia, Ukraine, Europe Google

https://scholar.google.com.ua/citations?hl=uk\&user=q3u7s38AAAAJ e-mail: alla0676128584@gmail.com

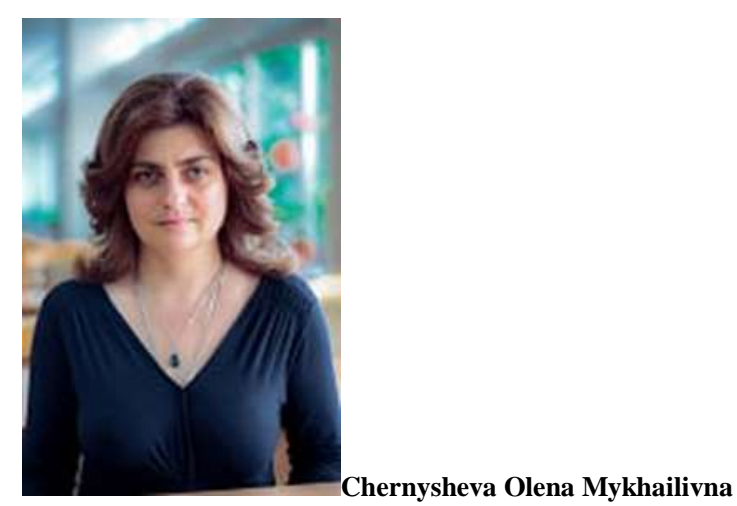

$\mathrm{PhD}$ in Economics, Associated Professor of Management and Finance Department, State Higher Education Institution "Ukrainian State University of Chemical Technology", Dnipro, Ukraine, Europe

Google

Scholar:

https://scholar.google.com/citations?user=qWoFALUAAAAJ\&hl=ru

e-mail: chernysheva197411@gmail.com 


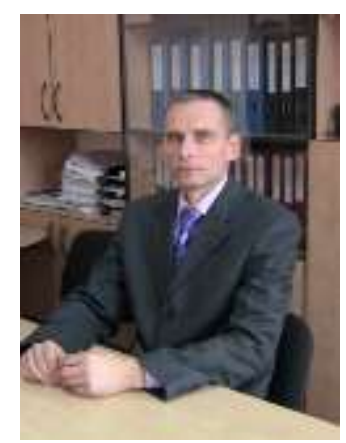

Sevast yanov Rodion Viktorovich

$\mathrm{PhD}$ in Economics, Associated Professor of

the Department of Entrepreneurship, Trade and Stock Exchange, National University "Zaporizhia Politechnic", Zaporizhia, Ukraine, Europe

Google Scholar:

https://scholar.google.com.ua/citations?

$\underline{\mathrm{hl}=\mathrm{uk} \& u \text { ser }=0 \mathrm{k} \_ \text {yMFgAAAAJ }}$

e-mail: rvs_zp@ukr.net

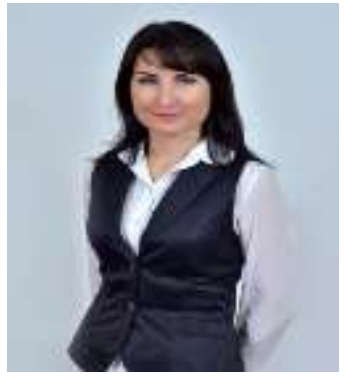

Krainik Olena Mykolayvna

$\mathrm{PhD}$ in Economics, Associated Professor of

the Department of Entrepreneurship, Trade and Stock Exchange, National University "Zaporizhia Politechnic", Zaporizhia, Ukraine, Europe Google

https://scholar.google.com.ua/citations?use r=BR_2_yQAAAAJ\&hl=ru

e-mail: elenakrainik2@gmail.com 